\title{
SYNTHESIS AND RELAXIVITY MEASUREMENTS OF NOVEL Gd(III)COMPLEX OF DOTVA AS MRA CONTRAST AGENTS
}

\author{
T. Lurthu Pushparaj1 ${ }^{\text {, V.Alexander }}{ }^{2}$ \\ 1Department of Chemistry, Einstein College of Engineering, Tirunelveli-627012 \\ 2Department of Chemistry, Loyola College, Chennai-600034 \\ Email: ${ }^{1}$ chemlurthu2006@gmail.com
}

\section{Abstract.}

The synthesis and relaxivity of a new gadolinium(III) complex of a polyazatricarboxylate macrocycle (DOTVA) having 2bromoisovaleric acid pendant arm is reported. The longitudinal relaxivity $\left(r_{1 p}\right)$ of $\left[\mathrm{Gd}(\mathrm{DOTVA})\left(\mathrm{H}_{2} \mathrm{O}\right)\right]$ is $6.72 \mathrm{mM}^{-1} \mathrm{~s}^{-1}(20 \mathrm{MHz}, 37 \pm$ $\left.0.1^{\circ} \mathrm{C}, \mathrm{pH} 7\right)$ which is higher than that of $\left[\mathrm{Gd}(\mathrm{DOTA})\left(\mathrm{H}_{2} \mathrm{O}\right)\right]^{-}\left(r_{1 \mathrm{p}}=4.2 \mathrm{mM}^{-1} \mathrm{~s}^{-1}, 20 \mathrm{MHz}\right)$ by $1.6 \%$ than the clinically approved CAs. The $r_{2 p} / r_{1 p}$ ratio for $\mathrm{Na}\left[\mathrm{Gd}(\mathrm{DOTVA})\left(\mathrm{H}_{2} \mathrm{O}\right)\right]$ is 1.16 showing that the complex is a $T_{1}$-weighted contrast agent. The complexes show $\mathrm{pH}$ dependent relaxivity at low and high $\mathrm{pH}$ values. It forms adduct with HSA and shows relaxivity enhancement. The 2bromoisovaleric acid seems to be an excellent pendant arm functionality in making new CAs for MRI and the amide core is a versatile core molecule for the creation of polynuclear gadolinium(III) chelates and dendrimeric CAs.

Key words. MRA Contrast agents, Blood Pool Agents, MRI, 2-bromoisovaleric acid, DOTVA

\section{INTRODUCTION}

In the world of medicine, magnetic resonance imaging (MRI) is the most important and prominent technique in biomedical research. ${ }^{1}$ The 2003 Nobel Prize for medicine was awarded to Professor Paul C. Lauterbur (Biomedical Magnetic Resonance Laboratory, University of Illinois) and Professor Sir Peter Mansfield (University of Nottingham) for their seminal discoveries concerning the use of magnetic resonance to visualize different structures leading to the development of modern MRI. ${ }^{2}$ Due to high spatial resolution, ${ }^{3} \mathrm{MRI}$ has become the clinical imaging procedure for a large number of studies involving the central nervous system, especially the brain, ${ }^{4}$ visualizing soft tissues, ${ }^{5}$ diagnosis of various diseases and the examination of almost all organs, ${ }^{6}$ and imaging of physiological properties such as diffusion, perfusion, and vascularity of tissues. ${ }^{3,7} \mathrm{MRI}$ also provides real-time images of visualizing drug delivery, ${ }^{8}$ monitoring biological processes, and following functional changes in vivo. ${ }^{8 a, 9}$ The image contrast obtained in MRI is a threedimensional signal intensity map of the spatially encoded proton signal of the in vivo water molecules in a given volume element (voxel). ${ }^{10}$ Contrast in MRI images arises from variations in the relaxation times among water protons caused by differences in the local environment in tissues. For many clinical applications, it is a common practice to administer an exogenous chemical, called contrast enhancing agent, to improve the image contrast. ${ }^{10 b}$ Currently, about $30 \%$ of the MRI examinations use contrast agents. ${ }^{5,11}$

Contrast agents can be divided into two classes depending on whether they cause changes in longitudinal relaxation time $\left(T_{1}\right)$ or transverse relaxation time $\left(T_{2}\right)$ of the water protons, known as positive and negative agents, respectively. ${ }^{12}$ The relaxivity reflect the efficiency of a contrast agent to accelerate longitudinal and transverse water proton relaxation rates $1 / T_{1}$ and $1 / T_{2}$, respectively, normalized to one millimole concentration of the agent. ${ }^{10 a, 13}$ The signal observed in MRI tends to increase with an increase in $1 / T_{1}$ and decrease with an increase in $1 / T_{2}$ and it is usual for contrast agents to affect both $1 / T_{1}$ and $1 / T_{2}$ to varying degrees. ${ }^{10 a}$ Positive contrast agents are commonly made up of paramagnetic materials, mainly those based on metal ions with large number of unpaired electrons such as $\mathrm{Mn}(\mathrm{II})$ and $\mathrm{Gd}(\mathrm{III})$. Positive contrast agents increase the brightness of 
images while the negative contrast agents give dark images. Superparamagnetic materials such as iron oxide nanoparticles are employed as negative CAs. ${ }^{1}$

Low molecular weight complexes of paramagnetic metal ions are administered as contrast agents prior to the acquisition of MRI images. ${ }^{1}$ Over the last decade there has been an increasing interest in the chemistry of $\mathrm{Gd}(\mathrm{III})$ complexes because they have been used in diagnostic medicine as contrast agents for MRI. The symmetric $S$-state of $\mathrm{Gd}(\mathrm{III})$ is a more hospitable environment for electron spins leading to a much slower electronic relaxation rate. Due to the large magnetic moment $\left(\mu_{\text {eff }}{ }^{2}=g^{2}(S(S+1))=63\right)$ with a long electron spin relaxation time $\left(10^{-9} s\right) \mathrm{Gd}(\mathrm{III})$ is widely used as a contrast agent for MRI. ${ }^{14}$ Free gadolinium ions get accumulated as phosphate salts in lysomes of heptocytes and macrophages in spleen, bone marrow, and lungs and as a result of its high in vivo toxicity $\mathrm{Gd}(\mathrm{III})$ ion is complexed with ligands to form stable complexes. 15 The commercially used contrast agents are $\mathrm{Gd}(\mathrm{III})$ complexes of polyaminocarboxylate ligands.

The choice of a contrast enhancing agent suitable for clinical use is governed by stringent biological requirements such as (i) high solubility in water (of the order of $0.5 \mathrm{M}$ ), (ii) effective catalyst for relaxation of protons in the bulk water, i.e., a high water proton relaxivity, (iii) better body distribution, (iv) low in vivo toxicity, i.e., extremely inert to the loss of the metal ion, (v) selective tissue/organ localization, (vi) rapid tissue clearance, and (vii) high thermodynamic stability and kinetic inertness. A sizable increase in relaxivity is achieved if $\mathrm{Gd}(\mathrm{III})$ chelates are covalently or noncovalently linked to macromolecules, because the rotational correlation time becomes comparable to or longer than the electronic and water-exchange correlation times. ${ }^{16}$ The conjugation of gadolinium(III)chelates to polymers, dendrimers, or biological molecules increases the rotational correlation time and improves the relaxivity "per Gd" atom. Targeting polynuclear conjugates are envisioned to provide MRI with the ability to image the low-concentration receptors by delivering a large payload of $\mathrm{Gd}(\mathrm{III})$ chelates. The present investigation could also be extended to the development of macromolecular CAs by appending the $\mathrm{Gd}(\mathrm{DO} 3 \mathrm{VA})$ chelate onto the macromolecular substrates such as polymers, ${ }^{17}$ proteins, and dendrimers. ${ }^{18}$

The mononuclear $\mathrm{Gd}(\mathrm{III})$ complexes of 2-isovaleric acid functionalized cyclen derivatives and polynuclear $\mathrm{Gd}(\mathrm{DO} 3 \mathrm{VA})$ complexes covalently conjugated to different amide linkers and core molecules can be subjected to detailed kinetic and pharmacokinetic studies to evaluate their suitability as contrast agents. Additional relaxivity gains may be achieved by increasing the number of the mobile protons of the amide linkers by the prototropic mechanism. The incorporation of 2-isovaleric acid groups is expected to increase the molecular weight as well as molecular dimension of the complex resulting in a longer rotational correlation time and thus leading to high proton relaxivity. The relaxivity of the mononuclear and polynuclear $\mathrm{Gd}$ (III) chelates of DO3VA depends on the residence time of the inner-sphere water molecules and the steric crowding and the formation of a secondary hydration sphere by the bulky 2-isovaleric acid group. Thus, there is a wide scope of studying the rotational dynamics and other relaxivity parameters for these systems. The gains made in the relaxivity of this monoand polynuclear gadolinium complexes would shed more light on the design parameters for future MRI contrast agents.

After the first generation clinically approved extracellular contrast agents, the next largest class of applications may involve blood pool agents that serve as contrast agents for MRI angiography. Magnetic resonance angiography represents a more attractive procedure for patients and doctors for vascular imaging. The addition of lipophilic groups to the carbon backbone of polyazapoly carboxylates profoundly alters the pharma cokinetic and biodistribution properties of their gadolinium complexes. Furthermore, the interaction of the $\mathrm{Gd}(\mathrm{DO} 3 \mathrm{VA})$ complexes with human serum albumin (HSA), their stability at the physiological $\mathrm{pH}$, and their vascular retention time can be studied to evaluate their suitability as contrast agents for magnetic resonance angiography (MRA). 


\section{EXPERIMENTAL SECTION}

\section{A. Materials.}

Bis(3-aminopropylamine), benzene- sulfonyl chloride, TRIS base, Celite ${ }^{\circledR}$, xylenol orange, and

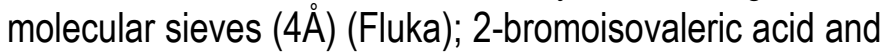
gadolinium(III) chloride (Aldrich); cyclen (Strem chemicals); and 2-chloroacetyl chloride, sodium bromide, potassium hydroxide, sodium hydroxide, disodium hydrogen phosphate, magnesium turnings, iodine, and sodium carbonate (anhydrous) (Merck, India) were used as such. Charcoal (Merck, India) was used for the purification of compounds after activating by heating at $150{ }^{\circ} \mathrm{C}$ overnight. Calcium chloride (anhydrous) and sodium wire (Merck, India) were used for drying purposes. Hydrochloric acid (AR, 35.4\%, $d=1.18$, Merck India) was used as supplied. Silica gel (blue indicator, Fluka) was used as desiccant after activating by heating in an oven at $200{ }^{\circ} \mathrm{C}$ overnight. Amberlite IR-120 $\left(\mathrm{H}^{+}\right.$ form, 16-45 mesh), Amberlite IR-400 (Cl- form, 20-50 mesh), Dowex 50W x 8-200 ( $\mathrm{H}^{+}-$form, $8 \%$ cross linking, 100-200 mesh), and Dowex $1 \times 8-400$ (Cl- form, $8 \%$ cross linking, 200-400 mesh) (Aldrich) were washed with double distilled water five times before use. $\mathrm{KBr}$ (FT-IR grade), DMSO- $d_{6}\left(99.9\right.$ atom $\% \mathrm{D}$ ), acetone- $d_{6}$ (99.9 atom $\%$ D), $\mathrm{D}_{2} \mathrm{O}$ (100 atom \% D) (Aldrich), and mineral oil (for IR spectroscopy, Fluka) were used as received. Super dry ethanol, super dry methanol, and triply distilled water were prepared by the standard procedures. ${ }^{15}$ HPLC grade water (Merck, India) was used to prepare solutions of the complexes for relaxivity measurements.

\section{METHODS}

\section{A. Physical Measurements.}

Infrared spectra were recorded on a Perkin-Elmer Spectrum RX-I FT-IR Spectrometer in the range of 4000 $400 \mathrm{~cm}^{-1}$. Spectra for the solid samples were recorded by making transparent $\mathrm{KBr}$ pellets. The electrospray ionization mass spectra were recorded on a micromass Quattro II triple quadrupole mass spectrometer. The sample dissolved in methanol, acetonitrile, or water was introduced into the ESI source through a syringe pump at the rate of $5 \mu \mathrm{L}$ per min. The ESI capillary was set at 3.5
$\mathrm{kV}$ and the cone voltage at $40 \mathrm{~V}$. The average spectra of 6-8 scans were printed. CHN microanalyses were carried out using a Perkin-Elmer 2400 Series II CHNS/O Elemental Analyzer interfaced with a Perkin-Elmer AD 6 Autobalance. Helium was used as the carrier gas. Caution! All hygroscopic compounds were dried in desiccator over silica gel for $24 \mathrm{~h}$ prior to the analysis. ${ }^{1} \mathrm{H}$ and ${ }^{13} \mathrm{C}$ NMR spectra were recorded on a Bruker AVANCE III $500 \mathrm{MHz}$ multinuclei NMR spectrometer. Broad band gradient probe head 'BBO' $5 \mathrm{~mm}$ probe was used for the ${ }^{1} \mathrm{H}$ NMR measurements. Inverse Quad Probe head $5 \mathrm{~mm}$ 'QXI' was used for the ${ }^{13} \mathrm{C}$ NMR measurements. $400 \mathrm{MHz}{ }^{1} \mathrm{H}$ NMR spectra were recorded on a Jeol GSX-400 multinuclear NMR spectrometer working at $25{ }^{\circ} \mathrm{C}$. The $100 \mathrm{MHz}{ }^{13} \mathrm{C}$ NMR spectra were recorded using Jeol GSX-400 instrument. The standard 5 $\mathrm{mm}$ probe was used for the ${ }^{1} \mathrm{H}$ and ${ }^{13} \mathrm{C}$ NMR measurements. $\mathrm{pH}$ measurements were made using Labindia $\mathrm{PICO}^{+} \mathrm{pH} /$ Conductive meter $(3 \mathrm{P})$ calibrated with buffer solutions of $\mathrm{pH} 4.0,7.0$, and 9.2.

\section{B. Longitudinal relaxivity measurements.}

The longitudinal relaxivity of the $\mathrm{Gd}(\mathrm{III})$ complexes were determined from the spin lattice relaxation time $\left(T_{1}\right)$. The $T_{1}$ measurements were carried out on a Bruker minispec $m q 20$ NMR Analyzer operating at a frequency of $20 \mathrm{MHz}$ and the temperature was maintained using a temperature console at $37 \pm 0.1^{\circ} \mathrm{C}$. The solutions of the complexes were taken in a $180 \times 10 \mathrm{~mm}$ stoppered glass tube. The instrument parameters were optimized for each $T_{1}$ measurement. Solutions of six concentrations $(0.2,0.5$, 1.0, 1.5, 2.0, and $2.5 \mathrm{mM}$ ) for each complex were prepared in HPLC grade water (Merck, India) in $5 \mathrm{~mL}$ standard measuring flask (Vensil, Class "A"). The presence of free gadolinium(III) ion in the solution has been checked by xylenol orange test. The $T_{1}$ measurements were made using the standard inversion recovery pulse sequence $\left(180^{\circ}-T-90^{\circ}\right)$ with phase sensitive detection with $T$ values ranging from $50 \mu \mathrm{s}$ to $6 \mathrm{~s}$ for each concentration of the complex. ${ }^{19}$ The computer program "Excel" (version 2007) was used to plot the time versus signal intensity to get a monoexponential plot and $T_{1}$ was calculated from the plot. The $T_{1}$ values for six concentrations of each complex were measured. The $T_{1}$ 
curves for all the concentrations have a monoexponential decay character. The longitudinal relaxivity was calculated from the slope of the regression line, obtained by the plot of the concentration of the complex versus $1 / T_{1}$ by least squares fitting method. The instrument was calibrated by measuring the relaxivity of $\left[\mathrm{Gd}(\mathrm{DO} 3 \mathrm{~A})\left(\mathrm{H}_{2} \mathrm{O}\right)_{2}\right]$ in aqueous solution $\left(r_{1 \mathrm{p}}=4.63 \mathrm{mM}^{-1} \mathrm{~s}^{-}\right.$ 1, $20 \mathrm{MHz}$ and $37^{\circ} \mathrm{C}$; lit. ${ }^{20} 4.80 \mathrm{mM}^{-1} \mathrm{~s}^{-1}, 20 \mathrm{MHz}, 40^{\circ} \mathrm{C}$ ).

\section{Transverse relaxivity measurements.}

The transverse relaxation time $\left(T_{2}\right)$ was determined by the standard Carr-Purcell-Meiboom-Gill (CPMG) pulse sequence $\left(90^{\circ}-T-180^{\circ}\right)$ with a $T$ value of $50 \mu s^{21}$ The computer program "Excel" (version 2007) was used to plot the time versus signal intensity to get an exponential curve and $T_{2}$ was calculated from the graph. The $T_{2}$ values for six concentrations were measured for each complex. The transverse relaxivity was calculated from the slope of the regression line, obtained by the plot of the concentration of the complex versus $1 / T_{2}$ by least squares fitting method. All other experimental conditions are the same as that employed for the $T_{1}$ measurements.

\section{SYNTHESIS OF LIGANDS AND COMPLEXES}

\section{A. 1,4,7,10-Tetraazacyclododecane-1,4,7,10-tetra- 2-isovaleric acid (DOTVA) (1).}

A solution of a-bromoisovaleric acid $(2.17 \mathrm{~g}, 12$ $\mathrm{mmol}$ ) in $50 \mathrm{~mL}$ of water was added dropwise to a suspension of cyclen $(0.52 \mathrm{~g}, 3 \mathrm{mmol})$ and sodium hydroxide $(0.48 \mathrm{~g}, 12 \mathrm{mmol})$ in $100 \mathrm{~mL}$ of water at $60^{\circ} \mathrm{C}$ for $1 \mathrm{~h}$. The reaction mixture was further heated to $70{ }^{\circ} \mathrm{C}$ and stirred under argon atmosphere for $36 \mathrm{~h}$, cooled to room temperature, filtered, flash evaporated, and dried in vacuum. The resulting pale yellow solid was washed with super dry methanol and recrystallized in water: yield (1.58 g, 92\%), mp $270{ }^{\circ} \mathrm{C}$. Anal. calcd. for $\mathrm{C}_{28} \mathrm{H}_{52} \mathrm{~N}_{4} \mathrm{O}_{8}\left(M_{\mathrm{r}}=\right.$ 573): C, 58.62; H, 9.15; N, 9.78. Found: C, 58.62; H, 9.10; N, 9.76. IR (KBr, cm-1): $3475 \mathrm{v}(\mathrm{O}-\mathrm{H})$ (acid), 2924 $\mathrm{v}(\mathrm{C}-\mathrm{H}), 1638 \mathrm{v}(\mathrm{C}=\mathrm{O})$ (acid), $1124 \mathrm{v}(\mathrm{C}-\mathrm{N})$ (tertiary amine), $617 \rho\left(\mathrm{CH}_{3}\right)$ (isopropyl group). MS (ESI): $\mathrm{m} / \mathrm{z} 569$ [M-4] $]^{+}$, $449\left[\mathrm{M}-\mathrm{C}_{2} \mathrm{H}_{4} \mathrm{O}_{6}\right]^{+}, 389\left[(\mathrm{M}-4)-\mathrm{C}_{6} \mathrm{H}_{12} \mathrm{O}_{6}\right]^{+}$.

\section{B. $\mathrm{Na}\left[\mathrm{Gd}(\mathrm{DOTVA}) \mathrm{H}_{2} \mathrm{O}\right](\mathrm{C} 1)$.}

A solution of the ligand 1 ( $2.86 \mathrm{~g}, 5 \mathrm{mmol})$ in $25 \mathrm{~mL}$ of water was added to a solution of $\mathrm{GdCl}_{3} .6 \mathrm{H}_{2} \mathrm{O}(1.85 \mathrm{~g}, 5$ $\mathrm{mmol}$ ) in $40 \mathrm{~mL}$ of water. The $\mathrm{pH}$ of the solution was maintained at 7 throughout the reaction by adding an aqueous solution of $\mathrm{NaOH}$ and heated to $60^{\circ} \mathrm{C}$ under argon atmosphere for about $12 \mathrm{~h} .{ }^{212}$ It was cooled to room temperature, filtered through a $0.2 \mu \mathrm{m}$ filter funnel, flash evaporated, and dried in vacuum. The resulting colorless hygroscopic solid was purified by column chromatography (Dowex ion exchange resin, cationic) using water and recrystallized in water: yield $(3.01 \mathrm{~g}, 81 \%)$. Anal. calcd. for $\mathrm{C}_{28} \mathrm{H}_{50} \mathrm{~N}_{4} \mathrm{O}_{9} \mathrm{GdNa}\left(\mathrm{Mr}_{\mathrm{r}}=767\right)$ : C, 45.14; $\mathrm{H}, 6.72 ; \mathrm{N}, 7.53$. Found: C, 45.12; $\mathrm{H}, 6.68 ; \mathrm{N}, 7.51$. IR $\left(\mathrm{KBr}, \mathrm{cm}^{-1}\right): 3414$ v(O-H), 2924 v(C-H), 1638 v(C=O) (acid), 1115 v(C-N) (tertiary amine), $621 \rho\left(\mathrm{CH}_{3}\right)$ (isopropyl group), $617 \rho(\mathrm{O}$ H), $532 \mathrm{\omega}(\mathrm{O}-\mathrm{H}), 482 \mathrm{v}(\mathrm{Gd}-\mathrm{O})$. MS (ESI): $\mathrm{m} / \mathrm{z} 767[\mathrm{M}]^{+}$, $725\left[(\mathrm{M}-1)-\mathrm{NaH}_{2} \mathrm{O}\right]^{+}, 551\left[(\mathrm{M}-1)-\mathrm{NaGdCH}_{5} \mathrm{O}_{2}\right]^{+}$.

\section{RELAXIVITY STUDIES}

\section{A. Longitudinal relaxivity of $\mathrm{Na}\left[\mathrm{Gd}(D O T V A)\left(\mathrm{H}_{2} \mathrm{O}\right)\right]$} (C1)

The longitudinal relaxation times of water proton for the neat aqueous solutions of $\mathrm{Na}\left[\mathrm{Gd}(\mathrm{DOTVA})\left(\mathrm{H}_{2} \mathrm{O}\right)\right]$ at six concentrations are given in Table 1 . The plot of the concentration of the complex versus $1 / T_{1}$ is given in

Figure 1. The longitudinal relaxivity of $\mathrm{Na}\left[\mathrm{Gd}(\mathrm{DOTVA})\left(\mathrm{H}_{2} \mathrm{O}\right)\right]$ is $6.72 \mathrm{mM}^{-1} \mathrm{~s}^{-1}$ which is 1.60 , $1.50,1.77,1.24,1.24,1.03,1.05$, and 1.01 units more than that of $\left[\mathrm{Gd}(\text { DOTA })\left(\mathrm{H}_{2} \mathrm{O}\right)\right]^{-}\left(r_{1 \mathrm{p}}=4.2 \mathrm{mM}^{-1} \mathrm{~s}^{-1}, 20\right.$ $\mathrm{MHz}$ ). The longitudinal relaxivity of $\mathbf{C 1}$ is also higher than that of the other monomeric complexes such as $[\mathrm{Gd}$ (synCy $y_{2}$ DOTA $\left.)\left(\mathrm{H}_{2} \mathrm{O}\right)\right] \quad\left(r_{1 \mathrm{p}}=4.5 \mathrm{mM}^{-1} \mathrm{~s}^{-1}, 20 \mathrm{MHz}\right)$, [Gd(DOTMA) $\left.\left(\mathrm{H}_{2} \mathrm{O}\right)\right]\left(r_{1 \mathrm{p}}=3.8 \mathrm{mM}^{-1} \mathrm{~s}^{-1}, 20 \mathrm{MHz}\right)$, [Gd(DOTA-PNB) $\left.\left(\mathrm{H}_{2} \mathrm{O}\right)\right]\left(r_{1 \mathrm{p}}=5.4 \mathrm{mM}^{-1} \mathrm{~s}^{-1}, 20 \mathrm{MHz}\right)$, [Gd(DOTA)- $\left.(\mathrm{BOM})\left(\mathrm{H}_{2} \mathrm{O}\right)\right]\left(r_{1 \mathrm{p}}=5.4 \mathrm{mM}^{-1} \mathrm{~s}^{-1}, 20 \mathrm{MHz}\right)$, [Gd(trans-DOTA $\left.)(B O M)_{2}\left(\mathrm{H}_{2} \mathrm{O}\right)\right] \quad\left(r_{1 \mathrm{p}}=6.5 \mathrm{mM}^{-1} \mathrm{~s}^{-1}, 20\right.$ $\mathrm{MHz}),[\mathrm{Gd}(\mathrm{DNA}-\mathrm{DOTA})]\left(r_{1 \mathrm{p}}=6.4 \mathrm{mM}^{-1} \mathrm{~s}^{-1}, 4 \mathrm{~T}\right)$, and $\left[\mathrm{Gd}(\mathrm{DOTA})(\mathrm{BOM})_{3}\left(\mathrm{H}_{2} \mathrm{O}\right)\right]\left(r_{1 \mathrm{p}}=6.7 \mathrm{mM}^{-1} \mathrm{~s}^{-1}, 20 \mathrm{MHz}\right)$, respectively. The $r_{1 \mathrm{p}}$ value is comparable to that of $\left[\mathrm{Gd}(\right.$ cis-DOTA $\left.)(\mathrm{BOM})_{2}\left(\mathrm{H}_{2} \mathrm{O}\right)\right] \quad\left(r_{1 \mathrm{p}}=6.8 \mathrm{mM}^{-1} \mathrm{~s}^{-1}, 20\right.$ $\mathrm{MHz}) .{ }^{44}$ The enhancement in the relaxivity of $\mathbf{C} 1$ when 
compare to other monomeric complexes with acetate pendant arms is attributed to an increase in the rotational correlation time $\left(T_{R}\right)$ due to an increase in the molecular dimension of the complex by the covalent conjugation of 2-isovaleric acid to the cyclen macrocycle.

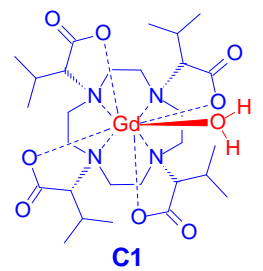

Fig.1 $\mathrm{Na}\left[\mathrm{Gd}(\mathrm{DOTVA})\left(\mathrm{H}_{2} \mathrm{O}\right)\right](\mathrm{C} 1)$

Table 1. Longitudinal relaxation times of $\mathrm{Na}\left[\mathrm{Gd}(\mathrm{DOTVA})\left(\mathrm{H}_{2} \mathrm{O}\right)\right]$

\begin{tabular}{lll}
\hline $\begin{array}{l}\text { Concentration } \\
(\mathrm{mM})\end{array}$ & $T_{1} \times 10^{-3} \mathrm{~S}$ & $1 / T_{1} \times 10^{3} \mathrm{~s}^{-1}$ \\
\hline 0.0 & 3425.78 & 00.29 \\
0.2 & 0689.65 & 01.45 \\
0.5 & 0296.73 & 03.37 \\
1.0 & 0144.93 & 06.90 \\
1.5 & 0097.28 & 10.28 \\
2.0 & 0073.42 & 13.62 \\
2.5 & 0058.79 & 17.01 \\
\hline
\end{tabular}

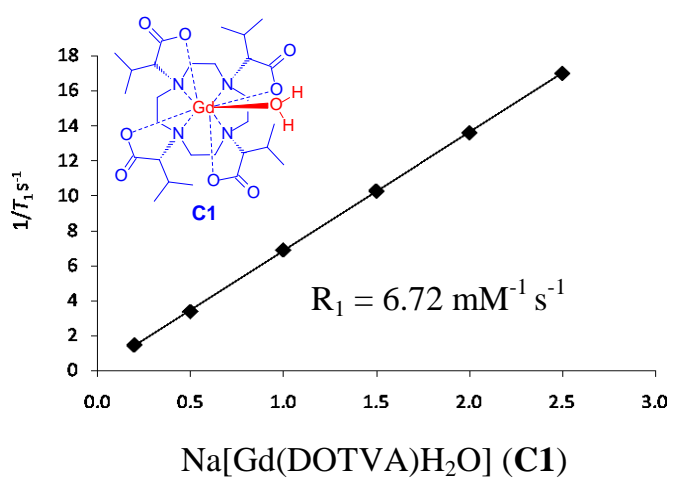

Fig. 2. Plot of the concentration of $\mathrm{Na}\left[\mathrm{Gd}(\mathrm{DOTVA}) \mathrm{H}_{2} \mathrm{O}\right]$ versus $1 / T_{1}$.

\section{B. Transverse relaxivity of $\mathrm{Na}\left[\mathrm{Gd}(D O T V A)\left(\mathrm{H}_{2} \mathrm{O}\right)\right]$ (C1)}

The transverse relaxation times for six concentrations of $\mathrm{Na}\left[\mathrm{Gd}(\mathrm{DOTVA})\left(\mathrm{H}_{2} \mathrm{O}\right)\right]$ are given in Table 2 and the plot of the concentration of the complex versus $1 / T_{2}$ is depicted in Figure 2. The transverse relaxivity is $7.81 \mathrm{mM}^{-1} \mathrm{~s}^{-1}$ which is 1.64 times higher than that of $\left[\mathrm{Gd}(\mathrm{DOTA})\left(\mathrm{H}_{2} \mathrm{O}\right)\right]\left(\mathrm{r}_{2 \mathrm{p}}=4.75 \mathrm{mM}^{-1} \mathrm{~s}^{-1}, 20 \mathrm{MHz}, 39\right.$ $\left.{ }^{\circ} \mathrm{C}\right)$. The higher $r_{2 p}$ value is attributed to the presence of a large number of water molecules hydrogen bonded to the periphery of the hydrophilic 2-isovaleric acid groups (outer-sphere mechanism). The $r_{2 p} / r_{1 p}$ ratio for $\mathrm{Na}\left[\mathrm{Gd}(\mathrm{DOTVA})\left(\mathrm{H}_{2} \mathrm{O}\right)\right]$ is 1.16 showing that the complex is a $T_{1}$-weighted contrast agent.

Table 2. Transverse relaxation times of $\mathrm{Na}\left[\mathrm{Gd}(\mathrm{DOTVA})\left(\mathrm{H}_{2} \mathrm{O}\right)\right]$

\begin{tabular}{lll}
\hline $\begin{array}{l}\text { Concentration } \\
(\mathrm{mM})\end{array}$ & $T_{2} \times 10^{-3} \mathrm{~S}$ & $1 / T_{2} \times 10^{3} \mathrm{~S}^{-1}$ \\
\hline 0.2 & 641.02 & 01.56 \\
0.5 & 256.41 & 03.93 \\
1.0 & 128.20 & 07.81 \\
1.5 & 085.47 & 11.71 \\
2.0 & 064.10 & 15.62 \\
2.5 & 051.28 & 19.53 \\
\hline
\end{tabular}

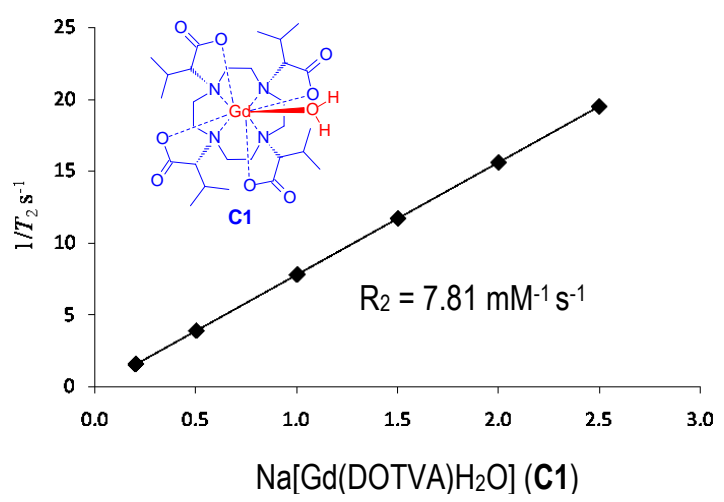

Fig. 3. Plot of the concentration of $\mathrm{Na}\left[\mathrm{Gd}(\mathrm{DOTVA}) \mathrm{H}_{2} \mathrm{O}\right]$ versus $1 / T_{2}$.

\section{C. $\mathrm{pH}$ Dependent Relaxivity of [Gd(DOTVA) $\left.\left(\mathrm{H}_{2} \mathrm{O}\right)\right]$ complex.}

The complex [Gd(DOTVA) $\left(\mathrm{H}_{2} \mathrm{O}\right)_{2}$ ] exhibits longitudinal relaxivities $\left(r_{1 \mathrm{p}}\right)$ of $11.05,11.31,12.38$, and $13.16 \mathrm{mM}^{-1} \mathrm{~s}^{-1}$ at $\mathrm{pH} 2.6,3.6,4.6$, and 5.6, respectively. These values are significantly higher than that of the complex in neat solution $\left(r_{1 \mathrm{p}}=5.32 \mathrm{mM}^{-1} \mathrm{~s}^{-1}, \mathrm{pH}=7\right)$. The relaxivity values at $\mathrm{pH}$ 
$7.2,7.5$, and 8.0 (TRIS-HCl buffer) are $4.90,6.10$, and 7.21, respectively. However, at pH 8.5, 9.6, and 10.6 the complex shows the longitudinal relaxivity of $0.90,0.74$, and 0.84 , respectively. The higher relaxivity at low $\mathrm{pH}$ may be caused by the protonation of the carboxylate oxygen, the nitrogen atoms of the ligand, and the water molecules hydrogen bonded to the periphery of the DOTVA chelates.

\section{Relaxivity of [Gd(DOTVA) $\left.\left(\mathrm{H}_{2} \mathrm{O}\right)\right]$ complex in the presence of HSA.}

The complex [Gd(DOTVA) $\left(\mathrm{H}_{2} \mathrm{O}\right)$ ] exhibits $r_{1 p}$ and $r_{2 p}$ values of 7.35 and $9.40 \mathrm{mM}^{-1} \mathrm{~s}^{-1}$, respectively, in the presence of HSA (1.36\%) which is 1.38 and 1.22 times higher than that of the complex in neat aqueous solution. The higher relaxivity of the complexes is due to the binding of the 2-isovaleric acid pendant arm with the serum protein which results in a higher rotational correlation time for the macromolecular adduct. This promises their use as blood pool CAs for magnetic resonance angiography.

\section{CONCLUSIONS.}

Improvements in MRI technology have enhanced the sensitivity of the technique. The sensitivity and selectivity of the technique is further improved by the relaxation efficiency of the CAs. Thus, the future is still bright for gadolinium(III)-based CAs. In the present investigation a convenient methodology has been developed for the synthesis of mono- and dinuclear gadolinium(III) complexes of 1,4,7,10-tetraazacyclodo- decane-1,4,7,10tetra-2-isovaleric acid DOTVA] as contrast enhancing agents for MRI. The 2-isovaleric acid pendant arm appears to be a versatile moiety in the development of new contrast agents for MRI. A new paradigmatic approach is demonstrated in developing a complex with good relaxivity value. The $\mathrm{pH}$-dependent relaxivity of the complexes could be exploited for their use as pH-responsive MRI contrast agents. Binding to HSA causes a significant increase in the relaxivity of the monomer. These complexes with the potential of binding with blood serum albumin through noncovalent interactions may offer a wide scope of evaluating their suitability as blood pool agents for MRA.

\section{ACKNOWLEDGMENT}

This research was carried out with the financial support from the Department of Biotechnology (DBT), Government of India. We thank Dr. M. S. Moni, Sophisticated Analytical Instrumentation Center, IIT-M, Chennai, for recording the NMR spectra and the Regional Sophisticated Instrumentation Center, CDRI, Lucknow, for recording ESI mass spectra

\section{REFERENCES}

[1] (a) Caravan, P.; Ellison, J. J.; McMurry, T. J.; Lauffer, R. B. Chem. Rev. 1999, 99, 2293-2352. (b) The Chemistry of Contrast Agents in Medical Magnetic Resonance Imaging; Merbach, A. E., Toth, E., Eds.; John Wiley \& Sons, Ltd.: New York, 2001. (c) Bottrill, M.; Kwok, L.; Long, J. N. Chem. Soc. Rev. 2006, 35, 557-571.

[2] Jendrasiak, L. G.; Smith, L. R.; Ribeiro, A. A. Phys. Med. Biol. 2000, 45, 3109-3122.

[3] Louie, A. Y.; Huber, M. M.; Ahrens, E. T.; Rothbacher, U.; Moats, R.; Jacobs, R. E.; Fraser, S. E.; Meade, T. J. Nat. Biotechnol. 2000, 18, 321-325.

[4] (a) Richardson, J. C.; Bowtell, R. W.; Mader, K.; Melia, C. D. Adv. Drug. Dev. Rev. 2005, 57, 1191-1209. (b) Ye, F.; Ke, T.; Jeong, E.-K.; Wang, X.; Sun, Y.; Johnson, M.; Lu, Z.-R. Mol. Pharm. 2006, 3, 507-515.

[5] Caravan, P. Chem. Soc. Rev. 2006, 35, 512-523.

[6] (a) Bianchi, A.; Calabi, L.; Corana, F.; Fontana, S.; Losi, P.; Maiocchi, A.; Paleari, L.; Valtancoli, B. Coord. Chem. Rev. 2000, 204, 309-393. (b) Brucher, E. Top. Curr. Chem. 2002, 221, 103-122.

[7] (a) Lauffer, R. E.; Chem. Rev. 1987, 87, 901-927. (b) Aime, S.; Botta, M.; Terreno, E. Adv. Inorg. Chem. 2005, 57, 173237. (c) Kubicek, V.; Toth. E. Adv. Inorg. Chem. 2009, 61, 63-129. (d) Gilsoul, D.; Hermann, M.; Humblet, V.; Jacques, V.; Mesbahi, M.; Sauvage, C.; Desreux, J. F. Coord. Chem. Rev. 1999, 185-186, 451-470. (e) Frullano, L.; Rohovec, J.; Peters, J. A.; Geraldes, C. F. G. C. Top. Curr. Chem. 2002, 221, 25-60. (f) Toth, E.; Helm, L.; Merbach, A. E. Top. Curr. Chem. 2002, 221, 61-101. (g) Aime, S.; Botta, M.; Fasano, M.; Crich, G. S.; Terreno, E. Coord. Chem. Rev. 1999, 185186, 321-333. (h) Chan, K. W.-Y.; Wong, W.-T. Coord. Chem. Rev. 2007, 251, 2428-2451. (i) Gries, H. Top. Curr. Chem. 2002, 221, 1-24. (j) Terreno, E.; Castelli, D. D.; Viale, A.; Aime, S. Chem. Rev. 2010, 110, 3019-3042. 
[8] Weinmann, H. J.; Brasch, R. C.; Press, W. R.; Wesby, G. E. Am. J. Roentgenol. 1984, 142, 619-624.

[9] (a) Penfield, J. G.; Reilly, R. F. Nat. Clin. Pract. Nephrol. 2007, 3, 654-668. (b) Gu, S.; Kim, H.-K.; Lee, H. G.; Kang, B.-S.; Chang, Y.; Kim, T.-J. J. Med. Chem. 2011, 54, 143152. (c) Villaraza, A. J. L.; Bumb, A.; Brechbiel, M. W. Chem. Rev. 2010, 110, 2921-2959.

[10] (a) Powell, D. H.; Dhubhghaill, O. M. N.; Pubanz, D.; Helm, L.; Lebedev, Y. S.; Schlaepfer, W.; Merbach, A. E. J. Am. Chem. Soc. 1996, 118, 9333-9346. (b) Toth, E.; Helm, L.; Merbach, A. E. In The Chemistry of Contrast Agents in Medical Magnetic Resonance Imaging; Merbach, A. E., Toth, E., Eds.; Wiley-VCH: Weinheim, Germany, 2001; Chapter 2, pp 45-119.

[11] (a) Caravan, P. Acc. Chem. Res. 2009, 42, 851-862. (b) Rebizak, R.; Schaefer, M.; Dellacherie, E. Bioconjugate Chem. 1998, 9, 94-99. (c) Siauve, N.; Clement, O.; Cuenod, C. A.; Benderbous, S.; Frija, G. Magn. Reson. Imaging 1996, 14, 381-390. (d) Kellar, K. E.; Henrichs, P. M.; Hollister, R.; Koenig, S. H.; Eck, J.; Wei, D. Magn. Reson. Med. 1997, 38, 712-716. (e) Zhou, Z.; Guo, J.; Yu, H.; Zhu, B.; Liu, C.; Jiang, X.; Zhang, M.; Chen, J. J. Magn. Reson. Imaging 2005, 22, 361-367. (f) Plush, E. S.; Woods, M.; Zhou, F.-Y.; Kadali, B. S.; Wong, S, M.; Sherry, A. D. J. Am. Chem. Soc. 2009, 131, 15918-15923. (g) Glogard, C.; Stensrud, G.; Aime, S. Magn. Reson. Chem. 2003, 41, 585588. (h) Nasongkla, N.; Bey, E.; Ren, J.; Ai, H.; Khemtong, C.; Guthi, J. S.; Chin, S.-F.; Sherry, A. D.; Boothman, D. A.; Gao, J. Nano Lett. 2006, 6, 2427-2430. (i) Margerum, L. D.; Campion, B. K.; Koo, M.; Shargill, N.; Lai, J. J.; Marumoto, A.; Sontum, P. C. J. Alloys Compds. 1997, 249, 185-190. (j) Toth, E.; Pubanz, D.; Vauthey, S.; Helm, L.; Merbach, A. E. Chem. Eur. J. 1996, 2, 1607-1615. (k) Nicolle, G. M.; Toth, E.; Schmitt-Willich, H.; Raduchel, B. E.; Merbach, A. E. Chem. Eur. J. 2002, 8, 1040-1048. (I) Rudovsky, J.; Hermann, P.; Botta, M.; Aime, S.; Lukes, I. Chem. Commun. 2005, 2390-2392.

[12] Hernandez, G.; Brittain, H. G.; Tweedle, M. F.; Bryant, R. G. Inorg. Chem. 1990, 29, 985-988.

[13] (a) Jebasingh. B.; Alexander. V. Inorg. Chem. 2005, 44, 9434-9443. (b) Toth, E.; Vauthey, S.; Pubanz, D.; Merbach, A. E. Inorg. Chem. 1996, 35, 3375-3379. (c) Bovens, E. Z.; Elst, L. V.; Muller, R. N.; Bekkum, H. V.; Peters, J. A. Eur. J. Inorg. Chem. 2001, 3101-3105. (d) Lee, T. M.; Cheng, T. H.; Ou, M. H.; Chang, C. A.; Liu, G. C.; Wang, Y. M. Magn. Reson. Chem. 2004, 42, 329-336. (e) Li, W. H.; Fraser, S. E.; Meade, T. J. J. Am. Chem. Soc. 1999, 121, 1413-1414. (f) Li, W. H.; Parigi, G.; Fragai, M.; Luchinat, C.; Meade, T. J. Inorg. Chem. 2002, 41, 4018-4024. (g) Ruloff, R.; VanKoten, G.; Merbach, A. E. Chem. Commun. 2004, 842843. (h) Livramento, J. B.; Toth, E.; Sour, A.; Borel, A.; Merbach, A. E.; Ruloff, R. Angew. Chem., Int. Ed. 2005, 44,
1480-1484. (i) Costa, J.; Toth, E.; Helm, L.; Merbach, A. E. Inorg. Chem. 2005, 44, 4747-4755.

[14] (a) Roglin, L.; Lempens, E. H. M.; Meijer, E. W. Angew. Chem., Int. Ed. 2011, 50, 102-112. (b) Mintzer, M. A.; Grinstaff, M. W. Chem. Soc. Rev. 2011, 40, 173-190. (c) Wiener, E.; Narayanan, V. In Advances in Dendritic Macromolecules; Newkome, G. R., Ed.; Elsevier Science Ltd.: New York, 2002; pp 129-247. (d) Dong, Q.; Hurst, D. R.; Weinmann, H. J.; Chenevert, T. L.; Londy, F. J.; Prince, M. R. Invest. Radiol. 1998, 33, 699-708. (e) Tacke, J.; Adam, G.; Claben, H.; Muhler, A.; Prescher, A.; Gunther, R. W. Magn. Reson. Imaging 1997, 7, 678-682. (f) Roberts, H. C.; Saeed, M.; Roberts, T. P. L.; Muhler, A.; Shames, D. M.; Mann, J. S.; Stiskal, M.; Demsar, F.; Brasch, R. C. Magn. Reson. Imaging 1997, 7, 331-338. (g) Roberts, H. C.; Saeed, M.; Roberts, T. P. L.; Brasch, R. C. Acad. Radiol. 1998, 5, S31-S33. (h) Xu, R.; Wang, Y.; Wang, X.; Jeong, K.-E.; Dennis, L.; Lu, R.-Z, Exp. Biol. Med. 2007, 232, 1081 1089. (i) Bryson, M. J.; Chu, W.-J.; Lee, J.-H.; Reinekebio, M. T. Bioconjugate Chem. 2008, 19, 1505-1509. (j) Wiener, E. C.; Brechbiel, M. W.; Brothers, H.; Magin, R. L.; Gansow, A.; Tomalia, D. A.; Lauterber, P. C. Magn. Reson. Med. 1994, 31, 1-8. (k) Langereis, S.; de Lussanet, G. Q.; Van Genderen, P. H. M.; Backes, H. W.; Meijer, E. W. Macromolecules 2004, 37, 3084-3091. (I) Langereis, S.; Dirksen, A.; de Waal, B. F. M.; Van Genderen, M. H. P.; de Lussanet, Q. G.; Hackeng, T. M.; Meijer, E. W. Eur. J. Org. Chem. 2005, 12, 2534-2538. (m) Floyd, W. C.; Klemm, P. J.; Smiles, D. E.; Kohlgruber, A. C.; Pierre, V. C.; Mynar, J. L.; Jean M. J. Frechet, J. M. J.; Raymond, K. N. J. Am. Chem. Soc. 2011, 133, 2390-2393.

[15] Furniss, B. S.; Hannaford, A. J.; Rogers, V.; Smith, P. W. G.; Tatchell, A. R.; Vogel's Textbook of Practical Organic Chemistry; $4^{\text {th }}$ ed: English Language Book Society; 1976; pp 457-458.

[16] Dawson, R. M. C.; Elliott, D. C.; Elliott, W. H.; Jones, K. M. Data for Biochemical Research; Oxford University Press: Oxford; 1969; pp 475-508.

[17] Pearse, A. G. E. In Histochemistry, Theoretical and Applied; Pearse, A. G. E., Ed.; Churchill Livingstone: Edinburgh, 1980; Vol. 1, p 167.

[18] (a) Gomori, G. Methods in Enzymology; Kaplan, N. O., Colowick, S. P., Ed.; Academic Press Inc.: New York; 1955; Vol. 1, p 138. (b) Sorensen, S. P. L. Biochem. Z. 1909, 22, 352375.

[19] Vold, R. V.; Waugh, J. S.; Klein, M. P.; Phelps, D. E. J. Chem. Phys. 1968, 48, 3831-3832.

[20] Shukla, R. B.; Kumar, K.; Weber, R.; Zhang, X.; Tweedle, M. F. Acta Radiologica 1997, 38, 121-123.

[21] Meiboom, S.; Gill, D. Rev. Sci. Instrum. 1958, 29, 688-691.

[22] Herzog, H. L. Org. Syn. 1972, 753-755. 
[23] (a) Nakamoto, K. Infrared and Raman Spectra of Inorganic and Coordination Compounds; $4^{\text {th }}$ ed; John-Wiley \& Sons, Inc.: New York, 1986. (b) Andre, J. P.; Maecke, H. R.; Toth, E.; Merbach, A. E. J. Biol. Inorg. Chem. 1999, 4, 341-347. (c) Silverstein, R. M.; Bassler, G. C.; Morrill, T. C. Spectrometric Identification of Organic Compounds; $5^{\text {th }}$ ed: John Wiley \& Sons, Inc.: New York, 1991.

[24] Kubieck, K.; Rudovsky, J.; Kotek, J.; Hermann, P.; Vander, L. E.; Muller, R. N.; Zvonimir, I. K.; Wolterbeek, H.; Peter, J. A.; Lukes, I. J. Am. Chem. Soc. 2005, 127, 16477-16485.

[25] Undheim, K.; Gronneberg, T. Acta Chem. Scand. 1971, 25, 18-26.
[26] Brunisholz, G.; Randin, M. Helv. Chim. Acta. 1959, 42, 1927-1938.

[27] (a) Paris, J.; Gameiro, C.; Humblet, V.; Mohapatra, K. P.; Jacques, V.; Desreux, F. J. Inorg. Chem. 2006, 45, 50925102. (b) Ranganathan, R. S.; Fernandez, M. E.; Kang, S. I.; Nunn, A. D.; Rastep, P. C.; Pillai, K. M. R.; Zhang, X.; Tweedle, M. F. Invest. Radiol. 1998, 33, 779-797. (c) Henig, J.; Toth, E.; Engelmann, J.; Gottschalk, S.; Mayer, A. H. Inorg. Chem. 2010, 49, 6124-6138. 